\title{
Comparative study of skull metastasis of thyroid carcinoma in Japan and Nigeria
}

\author{
Wilson Onuigbo* \\ Department of Pathology, Medical Foundation and Clinic, 8 Nsukka Lane, Enugu 400001, Nigeria
}

\begin{abstract}
Of late, there have been single case reports of thyroid carcinoma metastasizing to the skull. However, there is the sound idea that a histopathology data pool can help in advancing epidemiological research. Accordingly, on seeing a Japanese series in this field, my paper seeks to compare its reports with the findings accumulated personally in a Reference Histopathology Laboratory servicing a major Ethnic Group in Nigeria. The manifestations were found to be largely alike in both series except for relative proportion, sex factor and age range. Such comparisons are worthy of documentation in order to promote the international epidemiology of thyroid cancer.
\end{abstract}

\section{Introduction}

Single case reports appeared recently as regards individual patients in whom thyroid carcinoma spread to the skull [1-4]. However, comparison was made between a series reported from Japan [5] and the data collected from a Reference Regional Histopathology Laboratory serving the Igbo ethnic group in Nigeria [6]. The local materials were obtained personally following the recommendation that the histopathology data pool suffices to advance epidemiological knowledge.

\section{Materials and methods}

The cases of thyroid cancer documented at the Second Department of Surgery of Tohoku University and the Division of Neurosurgery, Institute of Brain Diseases in Japan during the 33 years from 1950 to 1982 were compared with those collected during 30 years from 1970 to 2000 at a Regional Pathology Laboratory situated in Enugu, Nigeria. The comparisons concerned such data as total thyroid cases, proportion of skull metastasis, sex and age, signs and symptoms, radiology and histopathology.

\section{Results}

Table 1 shows the basic findings. Similarities were noted in both series as follows:

1. Single palpable scalp swelling was the principal finding.

Table 1. Comparison of Japanese and Nigerian data on thyroid cancer spreading to the skull.

\begin{tabular}{|c|c|c|}
\hline Parameters & Japan & Nigeria \\
\hline Skull metastasis & 12 & 6 \\
\hline Females & 11 & 4 \\
\hline Males & 1 & 2 \\
\hline M/F ratio & $1: 11$ & $1: 2$ \\
\hline Age (Range) & $36-77$ & $40-61$ \\
\hline Age (Mean) & 60.4 & 50.1 \\
\hline
\end{tabular}

2. Just as a single bilateral Japanese case was encountered, a single case of multiplicity was seen in Nigeria.

3. As in a general publication, base of skull metastasis was conspicuously absent from both thyroid series.

4. Cranial nerve dysfunction was uncommon, occurring once in each series.

5. Skull X-ray films showed osteolytic lesions.

6. Histologically, follicular adenocarcinoma predominated with good differentiation.

7. There was a tendency towards long duration of growth unlike most other forms of cancer.

\section{Discussion}

Skull metastasis of thyroid carcinoma is uncommon in both Japan and Nigeria [8]. The several manifestations are lnargely alike in both countries except for relative proportion, sex factor and age range. As regards the important field of international epidemiology of cancer [9] such findings are of considerable interest.

It is the characteristic follicular pattern complete with colloid contents that gives away, as in this series, the diagnosis of metastatic thyroid malignancy. This is to the extent that Akdemir and his associates [10] on diagnosing the skull metastasis, went far and wide before they could confirm the thyroid origin.

Of some interest is the tendency of skull metastases to remain in the bone itself. Beyond it, there was the unusual picture of infiltration

Correspondence to: Wilson Onuigbo, Department of Pathology, Medical Foundation and Clinic, 8 Nsukka Lane, Enugu 400001, Nigeria, E-mail: wilson.onuigbo@gmail.com

Key words: thyroid, cancer, skull, epidemiology, Japan, Nigeria

Received: June 19, 2015; Accepted: July 23, 2015; Published: July 25, 2015 
of the brain. Incidentally, this was painted admirably by Sisson's group [11].

Significant also is the occasional invasion not of the skull but of the overlying scalp. Cupisti [12] and his associates demonstrated the case of the 76-year-old female patient in whom the lesion was so multicentric as to require closure with mesh graft. In this regard, a single instance of this type is in my possession. The 65-year-old woman had massive swellings measuring $20 \times 20 \times 15 \mathrm{~cm}$. The scalp itself was freely mobile over the skull. The diagnosis was "metastatic follicular carcinoma," while the comment was the crisp "The thyroid gland should be the primary site."

\section{References}

1. Kim SH, Kosnik E, Madden C, Morran S, Rusin J, et al. (1998) Lytic skull metastasis from a follicular thyroid carcinoma in a child.Pediatr Neurosurg 28: 84-88. [Crossref]

2. Yildirim T, Kayaselcuk F, Erdogan B, et al. (2004) Solitary skull metastasis of follicular thyroid carcinoma: CT and MR findings. Euro J Radiol 51:51-55.

3. Wani AM, Hussain WM, Fatani MI, et al. (2009) Skull metastases from thyroid carcinoma. Br Med J Case Rep.
4. Miyawaki S, Yamazaki R, Harada T, Takanashi S, Nagashima T, et al. (2007) Skull metastasis of thyroid papillary carcinoma. J Clin Neurosci 14: 481-484. [Crossref]

5. Nagamine Y, Suzuki J, Katakura R, Yoshimoto T, Matoba N, et al. (1985) Skull metastasis of thyroid carcinoma. Study of 12 cases. J Neurosurg 63: 526-531. [Crossref]

6. Basden GT (1966) Niger Ibos. London: Cass, 1966.

7. Macartney JC, Rollason TP, Codling BW (1980) Use of a histopathology data pool for epidemiological analysis. J Clin Pathol 33: 351-355. [Crossref]

8. Greenberg HS, Deck MD, Vikram B, Chu FC, Posner JB (1981) Metastasis to the base of the skull: clinical findings in 43 patients. Neurology 31: 530-537. [Crossref]

9. Waterhouse JA (1985) International epidemiology of cancer. J R Coll Physicians Lond 19: 10-12. [Crossref]

10. Akdemir I, Erol FS, Akpolat N, Ozveren MF, Akfirat M, et al. (2005) Skull metastasis from thyroid follicular carcinoma with difficult diagnosis of the primary lesion. Neurol Med Chir (Tokyo) 45: 205-208. [Crossref]

11. Sisson JC, Dewaraja YK, Wizauer EJ, Giordano TJ, Avram AM (2009) Thyroid carcinoma metastasis to skull with infringement of brain: treatment with radioiodine. Thyroid 19: 297-303. [Crossref]

12. Cupisti K, Ramp U, Raffel A, Krausch M, Rehders A, et al. (2008) Multiple giant scalp metastases of a follicular thyroid carcinoma. World J Surg Oncol 6: 82. [Crossref]

Copyright: (C2015 Onuigbo W. This is an open-access article distributed under the terms of the Creative Commons Attribution License, which permits unrestricted use, distribution, and reproduction in any medium, provided the original author and source are credited. 